\title{
Changes in lung function after exposure to vanadium compounds in fuel oil ash
}

\author{
R E M LEES \\ From the Occupational Health and Safety Resource Centre, Queen's University, Kingston, Ontario, \\ Canada
}

ABSTRACT Seventeen men were studied during the cleaning of bottom ash from the boiler of an oilfired electricity generating station. The men were exposed to a time weighted average respirable dust $(<10 \mu)$ of $523 \mu \mathrm{g} / \mathrm{m}^{3}$, containing $15.3 \%$ vanadium. Sixteen of the men wore respirators, subsequently found to have peak leakages of up to $9 \%$, while one volunteer had a one-hour exposure wearing only a compressed paper oronasal mask. Symptoms experienced by the men were recorded, urine samples were collected for assessment of vanadium concentration 24 hours after the first exposure, and spirometry was performed daily for four days and on the eighth day. Pronounced reductions in forced vital capacity (mean $0.5 \mathrm{l}$ ), forced expiratory volume (mean $0.5 \mathrm{l}$ ), and forced mid-expiratory flow (mean 1.16 l/s) had occurred within 24 hours of first exposure to the dust, and had not returned to pre-exposure levels by the eighth day. Four weeks after exposure no residual deficits were present. A urinary vanadium concentration of $280 \mu \mathrm{g} / 1$ was found in the volunteer, but none of the others had concentrations above the test-threshold of $40 \mu \mathrm{g} / \mathrm{l}$. Symptoms and signs of airway irritation were noted. The timing, duration, and quality of changes in lung function, however, indicated that the response could not be attributed solely to a reflex bronchial reaction to irritation by an inert dust.

Vanadium is an element widely distributed in nature and is found in small quantities in most foodstuffs. 1 Shellfish have a high content of the element, and it is from that source that vanadium in fuel oil originates.

The first report of occupational exposure to vanadium was made by Dutton in $1911 .^{2}$ He reported that men exposed to vanadium oxide in dust and fume complained of dry cough and eye irritation. In 1956 Gul'ko $^{3}$ reported that symptoms of respiratory tract irritation (sneezing, minor epistaxis, and coughing) and eye irritation were experienced by men occupationally exposed to dust containing a mixture of vanadium pentoxide, sodium, and ammonium metavanadate.These men were exposed to vanadiumbearing dust concentrations ranging from $3 \cdot 6^{\circ}$ to $25 \cdot 1$ $\mathrm{mg} / \mathrm{m}^{3}, 95 \%$ of which consisted of particles below $5 \mu$.

In 1955 Sjoberg examined seven men who cleaned large oil burners. ${ }^{4}$ Face masks of an unspecified type were worn by the men who subsequently complained

Received 1 June 1979

Accepted 30 July 1979 of eye irritation ( 3 cases), bronchial irritation (6), wheezing (5), cough (6), and dyspnoea (1). The signs and symptoms of respiratory irritation appeared one to two days after work had started and had disappeared within a few days of leaving the contaminated area.

In 1962 Zenz et $a l^{5}$ studied the effects of pure vanadium pentoxide inhaled, in concentrations believed to be greater than $0.5 \mathrm{mg} / \mathrm{m}^{3}$ of air, by 18 men. The complaints were as described above plus wheezing respiration, but on examination conjunctivitis, inflammation of the throat, and numerous pulmonary rales were found. These signs had disappeared in two weeks. Spirometry was not carried out at the time of exposure but two and four weeks later forced vital capacity (FVC) and forced expiratory volume in 1 second $\left(\mathrm{FEV}_{1}\right)$ were normal.

Zenz and Berg ${ }^{6}$ later exposed volunteers to air concentrations of $0.25 \mathrm{mg} / \mathrm{m}^{3}$ vanadium pentoxide for eight hours. All complained of cough within 24 hours, but this had settled in 7-10 days. Lung function tests did not alter from pre-exposure values. 
The study reported here was conducted at an oilfired electricity generating station comprising four separate boilers and turbines each with an output capacity of $550 \mathrm{Mw}$. The units were fired by Arabian oil with a vanadium content of $200 \mathrm{ppm}$. The products of combustion are recirculated through the boiler before being exhausted via precipitators to a $200 \mathrm{~m}$ stack. The combustible components of ash are thus burnt off leaving a high concentration of vanadium in the final waste product. Some of the final ash falls to the bottom of the boiler, the remainder being caught in the precipitators. The design of the boilers is such that much of the ash forms clinker on the sloping collection sides of the bottom hopper. Periodic removal of the ash and clinker necessitates the entry of men into the hopper to shovel out ash and break clinker with crowbars. This is a dusty operation, and the men engaged in it wear complete disposable coveralls and face masks fitted with cannister filters. Despite this many symptoms were reported by the men doing this job.

On two separate occasions I was able to observe 17 men exposed to bottom ash during cleaning operations. While the men work in crews of six to eight, with one supervisor, only two or three men work in the hopper at a time. They work in rotation so that during an eight-hour shift each man has about two hours of exposure to the dust.

The bottom ash at this generating station has an average vanadium content of $15.3 \%$, while the vanadium content of the crusted deposits, or clinker, has been measured at $24 \cdot 2$ to $35 \%$.

\section{Method of study}

Before exposure a medical history was taken from each man with particular emphasis on symptoms from the eyes, skin, and respiratory tract. A clinical pulmonary examination was made, and FVC and $\mathrm{FEV}_{1}$ measured on a Vitalograph Wedge Bellows spirometer. Three blows were made by the subjects on each occasion and the best performance recorded. From the spirometry graphs was calculated the forced mid-expiratory flow (FMF) - that is, the average rate of air flow between $25 \%$ and $75 \%$ of the FVC. All recordings were corrected to body temperature, normal barometric pressure, saturated (BTPS). A skin patch test was made on each man using a $2 \%$ aqueous solution of sodium vanadate and read 48 hours later.

Serial spirometry was performed on each subject at 24-hour intervals, starting on the day work began and for three days thereafter; a final spirometric record was obtained on the eighth day after initial exposure.

On the day after completing the cleaning operation the men were clinically examined and their symptoms were recorded. One man volunteered, for study purposes, to work for a one-hour period in the hopper wearing a compressed paper oronasal mask only.

\section{Results}

None of the 17 men gave a pre-exposure history of eye, skin, or respiratory symptoms, but a total of 44 symptoms were reported during the study (table 1). There were no positive patch skin tests.

Table 2 shows the serial FVC and FEV 1 values for 16 men, with the percentages of baseline values. Applying a paired " $t$ " test to the FVC and FEV 1 the differences between the baseline and lowest mean values were statistically significant at the levels shown. Because of the unique exposure of the volunteer, his spirometry values are listed separately in the table.

The figure illustrates graphically the changes in FVC and $F_{E V}$ after exposure for one man wearing respiratory protection (full face mask) and the volunteer.

Table 3 provides the baseline and expected and worst post-exposure FMF values for the 16 men (mean) and the volunteer. For the 16 men the range of fall in FMF values was from 9-31\%. Predicted, or expected, FMF values in litres per second were obtained for height and age from nomograms. ${ }^{7}$ Spirometry was repeated four weeks after exposure and was found to have returned to pre-exposure levels in all cases.

Clinical examination after dust exposure provided no surprises in the light of the reported symptoms. Coarse rhonchi were audible in all who complained of wheezing, while widespread rales were found in two others. No areas of consolidation were noted.

Single urine samples were obtained from the men on the morning after first exposure. Analysis of urine was carried out using flameless atomisation atomic absorption with simultaneous background

Table 1 Distribution and frequency of symptoms after exposure to vanadium-containing bottom ash $(n$ exposed $=17)$

\begin{tabular}{lcc}
\hline Symptom & Number & $\%$ \\
\hline Cough with sputum & 13 & 77 \\
Respiratory wheeze & 9 & 53 \\
Sore throat & 7 & 41 \\
Rhinitis & 5 & 29 \\
Headache & 3 & 18 \\
Dry cough & 3 & 18 \\
Eye irritation & 2 & 12 \\
Tongue discoloration & 1 & 6 \\
Epistaxis & 1 & 6 \\
Itch or rash & 0 & 0 \\
Total & 44 & \\
\hline
\end{tabular}


Table 2 Serial spirometry in litres. Mean values for 16 subjects before and after exposure

\begin{tabular}{|c|c|c|c|c|}
\hline & FVC & $F E V_{1}$ & $\% F V C$ & $\% F E V_{1}$ \\
\hline $\begin{array}{l}\text { Baseline } \\
\text { (SD) }\end{array}$ & $\begin{array}{c}5 \cdot 3 \\
\pm 0.74\end{array}$ & $\begin{array}{c}4 \cdot 5 \\
\pm 0.38\end{array}$ & 100 & 100 \\
\hline Postexposure day 1 & $5 \cdot 2$ & 4.4 & $98 \cdot 1$ & $\mathbf{9 7 \cdot 7}$ \\
\hline 2 & $4 \cdot 8$ & 3.9 & $90 \cdot 5$ & 86.6 \\
\hline 3 & $4 \cdot 7$ & $4 \cdot 0$ & $88 \cdot 6$ & $88 \cdot 8$ \\
\hline 4 & 4.9 & $4 \cdot 1$ & $94 \cdot 0$ & $91 \cdot 0$ \\
\hline 8 & $5 \cdot 2$ & $4 \cdot 3$ & $98 \cdot 1$ & $95 \cdot 5$ \\
\hline $\begin{array}{l}\text { Lowest mean value } \pm S D \\
\text { Significance of difference between means }\end{array}$ & $\begin{array}{l}\quad 4.7 \pm 0.38 \\
\mathrm{p}<0.05 \\
(t=2.2)\end{array}$ & $\begin{array}{l}\quad 3.9 \pm 0.4 \\
\mathrm{p}<0.001 \\
(t=3.75)\end{array}$ & $88 \cdot 6$ & 86.6 \\
\hline \multicolumn{5}{|l|}{ Volunteer } \\
\hline Baseline & 5.9 & $4 \cdot 7$ & 100 & 100 \\
\hline Postexposure day 1 & $3 \cdot 15$ & $2 \cdot 6$ & 53.4 & $55 \cdot 3$ \\
\hline 2 & 3.75 & $2 \cdot 8$ & $63 \cdot 5$ & $59 \cdot 5$ \\
\hline 3 & $5 \cdot 0$ & $3 \cdot 0$ & $84 \cdot 7$ & $63 \cdot 8$ \\
\hline
\end{tabular}

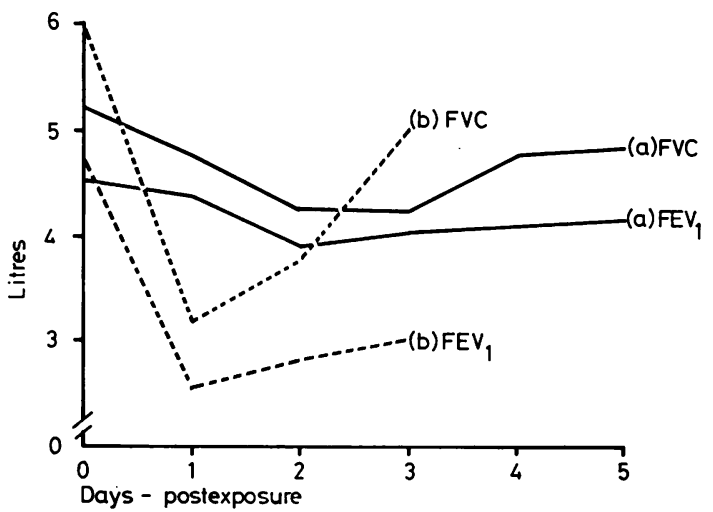

FVC and FEV 1 changes after light exposure (a) and heavy exposure (b).

correction. Only the volunteer, with a vanadium concentration of $280 \mu \mathrm{g} / 1(5.488 \mu \mathrm{mol} / \mathrm{l})$ exceeded the threshold of $40 \mu \mathrm{g} / 1(0.784 \mu \mathrm{mol} / \mathrm{l})$ set for this test. Two percent of the dust comprised particles of less than $10 \mu$ size. Personal sampling of respirable dust (under $10 \mu$ ) at the breathing zone was undertaken from four of the men and indicated a mean time weighted average of $523 \mu \mathrm{g} / \mathrm{m}^{3}$, suggesting a total dust concentration in excess of $26 \mathrm{mg} / \mathrm{m}^{3}$.

\section{Discussion}

The atmosphere in the bottom ash hoppers becomes extremely dusty during cleaning. The threshold limit value for vanadium (total dust) is $0.5 \mathrm{mg} / \mathrm{m}^{3} .8$
While working in the hoppers the men were protected by full disposable coveralls and cartridge filter type respirators. Subsequent tests indicated peak leakages of up to $9 \%$ in the respirators due to imperfect facial sealing. It is not possible from the data available to calculate accurately the amount of dust inhaled, but analysis of urine for vanadium content in 16 subjects did not show its presence above the test threshold of $40 \mu \mathrm{g} / \mathrm{l}(0 \cdot 784 \mu \mathrm{mol} / \mathrm{l})$ of urine.

The volunteer wearing poor protective equipment experienced severe discomfort 18 hours after exposure and had a urinary vanadium concentration of $280 \mu \mathrm{g} / \mathrm{l}(5.488 \mu \mathrm{mol} / \mathrm{l}) 24$ hours after exposure.

A more sensitive urinary analytical technique for measuring vanadium concentrations in single, small volume specimens has since been developed (Page $\mathbf{J}$, unpublished work) and is now being used in further studies. Men studied subsequently have been found to have postexposure urinary vanadium concentrations of $26-33 \mu \mathrm{g} / \mathrm{l}(0.509-0.647 \mu \mathrm{mol} / \mathrm{l})$. The corresponding figure in normal subjects without occupational exposure is less than $0.2 \mu \mathrm{g} / 1(0.0039$ $\mu \mathrm{mol} / \mathrm{l}){ }^{1}$

In contrast to the findings of Zenz et al ${ }^{5}$ and Zenz and Berg ${ }^{6}$ there were pronounced changes from baseline values for FVC, FEV 1 , and FMF after exposure to the dust. Changes began within 24 hours after exposure and had not recovered by the eighth day. Because of the work patterns of those concerned it was not possible to follow the volunteer's lung function over the eight days, but the data in table 2 suggest, by extrapolation of the line of recovery of lung function, that a period of about ten days is

Table $3 F M F(l / s)$ changes after exposure to vanadium-containing dust

\begin{tabular}{lllllc}
\hline & Baseline & Expected & $\begin{array}{l}\text { Minimum } \\
\text { postexposure }\end{array}$ & \multicolumn{2}{l}{ Reduction } \\
\cline { 5 - 6 } & & & Flow rate & $\%$ \\
\hline Mean (SD) & $5 \cdot 06$ & $5 \cdot 03$ & $3 \cdot 9$ & $1 \cdot 16( \pm 0 \cdot 82)$ & 23 \\
Range & $3 \cdot 1-7 \cdot 9$ & $4 \cdot 5-5 \cdot 5$ & $2 \cdot 6-5 \cdot 5$ & $0 \cdot 33-2 \cdot 4$ & $9-31$ \\
Volunteer & $2 \cdot 9$ & $4 \cdot 5$ & $2 \cdot 15$ & $0 \cdot 75$ & 26 \\
\hline
\end{tabular}


required to return to baseline values.

Only one of the 16 men, for whom results are presented, smoked cigarettes. His changes in pulmonary function were not more severe than those of his colleagues.

Exposure to heavy concentrations of inert dusts causes only transitory and slight changes in $\mathrm{FEV}_{1 .}{ }^{9}$ Musk et al ${ }^{10}$ observed $\mathrm{FEV}_{1}$ declines of $0 \cdot 11$ or more in Boston firemen in $30 \%$ of fire attendances. The declines in $\mathrm{FEV}_{1}$ persisted for several hours and in one case for days. That suggested they were observing more than a reflex respiratory response to particulates and that local pharmacological activity or chemical stimulation of bronchial receptors was occurring. In the present study of 16 subjects the mean postexposure decline in $\mathrm{FEV}_{1}$ was 0.51 along with a mean decline of $1 \cdot 16 \mathrm{l} / \mathrm{s}$ in FMF. A substantial decline (mean 0.51 ) was also noted in the FVC, suggesting that a restrictive condition was also present. The clinical findings of rales in two cases and the extent of the fall in FVC relative to the fall in FEV (fig) suggest that there was alveolar involvement.

All the symptoms encountered have been reported previously by other authors. Only one observation of greenish-black tongue discoloration was made. That sign is thought to be evidence of exposure only and not a manifestation of toxicity. I noted this colour change after applying some dust to the moist tongue without having had any other exposure to vanadium.

Generally symptoms disappeared within four days of the end of exposure, but half of the men who complained of cough continued to have it until the sixth day. All abnormalities noted on auscultation had disappeared within five days. Thus symptoms and signs associated with exposure had resolved several days before lung function tests had returned to pre-exposure levels.

These findings give rise to some concern. The provision of full-face cartridge type respirators cannot be guaranteed to provide complete protection from vanadium dust or respiratory tract irritation.
Two alternative types of protection are being tested.

The amount of vanadium absorbed should be measurable by quantitative urinary analysis, thus providing a biological assessment of respiratory mask efficiency. Two of the men complained of no symptoms but did show diminution of lung function. Thus symptoms, by themselves, may not provide reliable evidence of toxic effects.

Because of the magnitude of the observed changes in lung function there may be some risk of irreversible deterioration of pulmonary performance if repeated exposures are being experienced. Routine annual spirometry is indicated for all men exposed to vanadium compounds until the long-term pulmonary effects can be determined.

I acknowledge the support of Ontario Hydro in conducting this study and express my appreciation to the employees of the Lennox Generating Station for their co-operation. The capable help of Carole Wilson, BNSc, RN, is gratefully acknowledged.

\section{References}

${ }^{1}$ Byrne AR, Kosta L. Vanadium in foods and human body fluids and tissues. Sci Total Environ 1978;10:17-30.

${ }^{2}$ Dutton WF. Vanadiumism. JAMA 1911;1:1648-52.

${ }^{3}$ Gul'ko AG. Characteristics of vanadium as an industrial poison. Gig Sanit 1956;21:24-8.

${ }^{4}$ Sjoberg SG. Vanadium bronchitis from cleaning oil fired burners. AMA Arch Ind Health 1955;11:505-12.

${ }^{5}$ Zenz C, Bartlett JP, Thiede WH. Acute vanadium pentoxide intoxication. Arch Environ Health 1962;5:542-6.

- Zenz C, Berg BA. Human responses to controlled vanadium pentoxide exposure. Arch Environ Health 1967;14:70912.

${ }^{7}$ Kambouroff PL, Woitowitz HJ. Lung function tables and nomograms. England: Vitalograph Ltd, 1977.

${ }^{8}$ Threshold limit values for chemical substances in workroom air. Cincinnati: American Conference of Governmental Industrial Hygienists, 1978.

${ }^{9}$ McDermott M. Acute respiratory effects of coal dust particles. J Physiol 1962;162:52.

${ }^{10}$ Musk AW, Smith TJ, Peters JM, McLaughlin E. Pulmonary function in firefighters-acute changes in ventilatory capacity. Br J Ind Med 1979;36:29-34. 